\title{
The Asia 2 specific signal peptide region and other domains in fusion protein genes characterized Asia I and Asia 2 canine distemper viruses
}

\author{
Serageldeen Sultan ${ }^{1}$, Nataya Charoenvisal2 ${ }^{2}$ Nguyen Thi Lan ${ }^{2,3}$, \\ Ryoji Yamaguchi ${ }^{2}$, Ken Maeda ${ }^{1}$ and Kazushige Kai*1
}

Address: ${ }^{1}$ Department of Veterinary Microbiology, Faculty of Agriculture, Yamaguchi University, Yamaguchi 753-8515, Japan, ${ }^{2}$ Department of Veterinary Pathology, Faculty of Agriculture, University of Miyazaki, Miyazaki 889-2192, Japan and 32Department of Veterinary Pathology, Faculty of Veterinary Medicine, Hanoi University of Agriculture, Trau Quy-Gia Lam-Ha Noi, Vietnam

Email: Serageldeen Sultan - seaas@lycos.com; Nataya Charoenvisal - a0d402u@cc.miyazaki-u.ac.jp; Nguyen Thi Lan - a0d402u@cc.miyazakiu.ac.jp; Ryoji Yamaguchi - a0d402u@cc.miyazaki-u.ac.jp; Ken Maeda - kmaeda@yamaguchi-u.ac.jp; Kazushige Kai* - kzkai@yamaguchi-u.ac.jp

* Corresponding author

Published: 6 October 2009

Virology Journal 2009, 6:157 doi:10.1186/1743-422X-6-157

This article is available from: http://www.virologyj.com/content/6/1/157

(c) 2009 Sultan et al; licensee BioMed Central Ltd.

This is an Open Access article distributed under the terms of the Creative Commons Attribution License (http://creativecommons.org/licenses/by/2.0), which permits unrestricted use, distribution, and reproduction in any medium, provided the original work is properly cited.
Received: 5 August 2009

Accepted: 6 October 2009

\begin{abstract}
Background: Although the presence of Asia 2 group of canine distemper virus (CDV) was known by the sequencing and phylogenetic analysis of hemagglutinin $(H)$ gene, the fusion $(F)$ protein gene sequence of Asia 2 group had not been identified. So, the sequence analysis of $F$ gene was carried out to elucidate the genotypic varaitons among Asian isolates.

Results: The phylogenetic analysis of $\mathrm{F}$ and $\mathrm{H}$ gene sequences from fourteen $\mathrm{CDV}$ isolates obtained from diseased dogs in Japan and Thailand indicated that the $F$ genes had a new initiation codon and extra 27 nucleotides upstream of the usual open reading frame (ORF) and the $F$ proteins had extra 9 amino acids at the $\mathrm{N}$-terminal position only in Asia 2 isolates. On the contrary, the Asia $\mathrm{I}$ isolates had three extra putative $\mathrm{N}$-glycosylation sites (two sites in the signal peptide region and one site in the $\mathrm{FI}$ region) except for two strains of ThI2 and Ac96I (two sites in signal peptide region) adding to four putative $\mathrm{N}$-glycosylation sites that were conserved among all Asian isolates and Onderstepoort strain. In addition to this difference in $\mathrm{N}$-glycosylation sites, the signal peptide region had a great diversity between Asia I and Asia 2 isolates. Also, characteristic amino acids were detected for some strains.

Conclusion: Asia 2 isolates were distinguished from other CDV lineages by the extra 27 nucleotide sequence. The signal peptide region of $F$ gene gives a remarkable differentiation between Asia I and Asia 2 isolates. Strains Th 12 and Ac96I were differentiated from other Asia I strains by the $\mathrm{F}$ protein glycosylation sites.
\end{abstract}

\section{Background}

Canine distemper virus (CDV) is a single strand RNA virus belonging to genus Morbillivirus within the family Para- myxoviridae. The CDV genome encodes the following virion proteins: nucleocapsid $(\mathrm{N})$, phosphoprotein $(\mathrm{P})$, matrix $(\mathrm{M})$, fusion $(\mathrm{F})$, hemagglutinin $(\mathrm{H})$ and polymer- 
ase (L). The F protein mediates $\mathrm{pH}$-independent fusion of the viral envelope with the plasma membrane of the host cell [1].

Paramyxovirus fusion proteins are synthesized as an inactive precursor F0 that is cleaved by a host-cell protease to release the new N-terminus of the F1 [2]. Thus, forming the biologically active protein consists of the disulfide linked chain F1 and F2 [3]. The membrane anchored F1 subunit contains several regions important for promotion of membrane fusion. At its C-terminus, a hydrophobic trans-membrane domain (TM) anchors the protein in the membrane leaving a short cytoplasmic tail (20-40 residues). The fusion peptide, locates at the F1 subunit N-terminus, has been demonstrated to insert into the target membrane upon initiation of membrane fusion [4]. Also, F1 contains two heptad repeat regions, one close to C-terminal of the fusion peptide (HRA) and the other adjacent to the trans-membrane domain (HRB) $[2,5,6]$. To date, intensive studies were carried out on the $\mathrm{H}$ gene sequencing and phylogenetic relationship analysis [7-14] but a little is known about the F gene variations. Two genotypes of $\mathrm{H}$ gene, Asia $1[9,15]$ and Asia 2 [12], have been recognized among Asian isolates of CDV and they were found to differ from those of the European and American CDV genomes. In this study the phylogenetic characterization of $\mathrm{F}$ as well as $\mathrm{H}$ protein genes among Asian isolates of $\mathrm{CDV}$ was carried out to know the genetic variations of $\mathrm{F}$ genes.

\section{Results}

Phylogenetic analysis of deduced amino acids of $\boldsymbol{H}$ genes The phylogenetic relationship based on the deduced amino acid sequences of the $\mathrm{H}$ protein of fourteen CDV strains were analyzed as shown in Fig. 1. As a result, strains 007Lm, 55L, 66L, 009L, M25CR, 011C, 50Con and $50 \mathrm{Cbl}$ were classified into Asia 2 group and strains Ac96I, Th12, 50Sc, 81ND, 82Con and $83 \mathrm{mLN}$ were classified into Asia 1 group. Among the Asia 2 strains, 007Lm, 66L, 009L, M25CR, and 011C had identical amino acid sequences of the $\mathrm{H}$ gene, although strain 009L differed from strains $007 \mathrm{Lm}, 66 \mathrm{~L}, \mathrm{M} 25 \mathrm{CR}$, and $011 \mathrm{C}$ in its nucleotide sequence of the H gene (99\% identity). In addition, these four strains differed from strains 55L, 50Con, and $50 \mathrm{Cb} 1$ in both amino acid and nucleotide sequences (99\% identity of both amino acid and nucleotide sequences). On the other hand, among the Asia 1 strains, 50Sc, 82Con, and 83mLN had identical amino acid sequences of the $\mathrm{H}$ gene although strain $82 \mathrm{Con}$ differed from strains $50 \mathrm{Sc}$ and $83 \mathrm{mLN}$ in the nucleotide sequences of the $\mathrm{H}$ gene (99\% identity). However, these three strains differed from strains Ac96I, Th12, and 81ND in both amino acid (identity 99\% with Ac96I and 81ND, and 98\% with Th12) and nucleotide sequence (identity 99\% with Ac96I and 81ND, and 98\% with Th12).

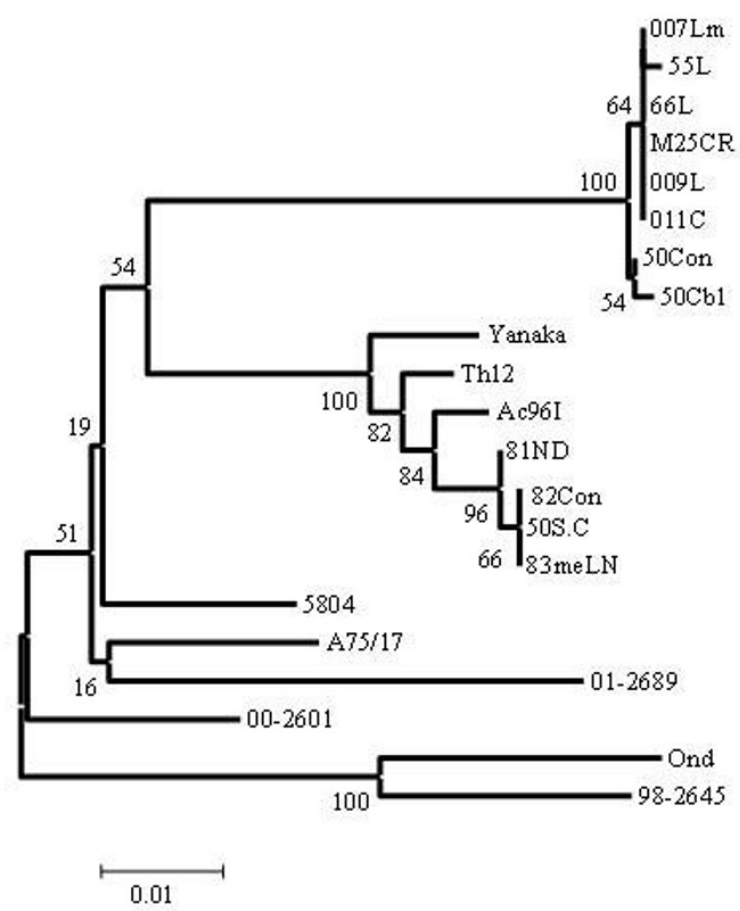

Figure I

Phylogenetic analysis of deduced amino acid sequences of $\mathbf{H}$ gene of Asian isolates of canine distemper virus using the neighbor-joining method in Mega 3.I program. Accession numbers of CDV used for comparison are shown in parentheses as follows: A75/I7 (AFI64967), 5804 (AY3863I5), 00-260I (AY443350), 0I2689 (AY649446), 98-2645 (AY445077), Yanaka (D87949) and Onderstepoort (AF378705).

\section{Extra 27 nucleotides upstream of the usual $F$ gene initiation codon characterized Asia 2 strains}

Sequence analyses of the F gene revealed a new initiation codon and extra 27 nucleotides upstream of the usual $\mathrm{F}$ gene open reading frame (ORF) in all Asia 2 isolates. To characterize this nucleotide sequence, which extended from 4908 to 4934 , various CDV strains as well as the present fourteen strains were compared about the nucleotide sequences from 4901 to 4940 as shown in Fig. 2. Interestingly, only Asia 2 isolates have a nucleotide change from ${ }^{4909} \mathrm{G}$ to ${ }^{4909} \mathrm{~T}$ which led to the expansion of the F ORF. All Asia 2 isolates (007Lm, 55L, 66L, 009L, M25CR, 011C, 50Con and 50Cbl) had an identical 27 nucleotide sequence. In addition, other nucleotide differences were found among Asia 2 isolates such as ${ }^{4907} \mathrm{~T} /$ ${ }^{4907} \mathrm{C}$ that characterized $50 \mathrm{Con}$ and $50 \mathrm{Cbl}$ from other strains, also ${ }^{4920} \mathrm{G} /{ }^{4920} \mathrm{~A}$ and ${ }^{4930} \mathrm{~T} /{ }^{4930} \mathrm{G}$ characterized all Asia 2 strains although American and European as well as Yanaka (Asia 1) strains have the same nucleotide at position 4920 as Asia 2 isolates. The ${ }^{4926} \mathrm{~A}$ and ${ }^{4928} \mathrm{~A}$ were shared by all strains in compared to Onderstepoort strain (Fig. 2). 


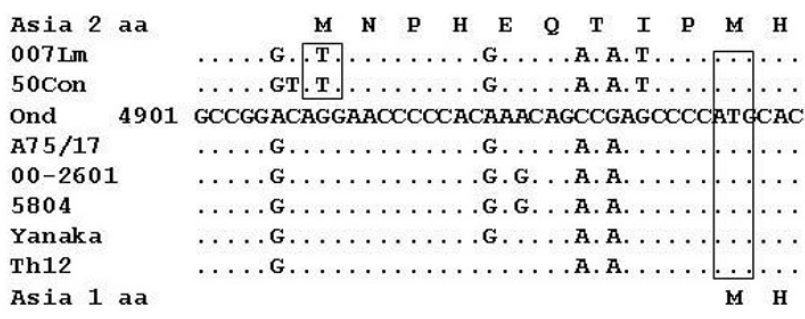

Figure 2

Alignment of the nucleotide sequences of different CDV field isolates and Onderstepoort strain from nt 490 I to 4940 upstream of the usual initiation codon of F gene ORF (start from nt 4935) showing the extra 27 nucleotides and their deduced 9 amino acids in Asia 2 isolates. The following strains had identical sequences; Asia 2 strains (007Lm, 55L, 66L, 009L, M25CR and $0 \mathrm{II} \mathrm{C}$ ), (50Con and $50 \mathrm{Cbl}$ ), Asia I strains (ThI2, Ac96I, 50Sc, $81 \mathrm{ND}, 82 \mathrm{Con}$ and $83 \mathrm{mLN}$ ) and American strains (982645, 00-260I and 0I-2689). Accession numbers as in Fig. I.

Structure of the $\boldsymbol{F}$ gene product and cleavage sites stability The $\mathrm{F}$ genes of fourteen Asian CDV isolates were sequenced and the deduced amino acids were aligned to detect the genetic variations among Asian isolates as shown in Fig. 3. The F gene product is cleaved by cellular proteases of signal peptidase and furin into three regions; signal peptide, F2 and F1 [2]. The cleavage sites, AQIHW in the C-terminus of signal peptide region and RRQRR in the N-terminus of F1 region [16-18], were highly conserved in all Asian isolates as shown in Fig. 3.

\section{Signal peptide region}

The signal peptide region is an important region for location of the precursor F0 into golgi network to cleave into F1 and F2 for fusion activity [19] and is a highly divergent region [2]. As shown in Fig. 3 all Asia 2 isolates have extra 9 amino acids upstream of the $\mathrm{N}$-terminus of this region which is a characteristic for Asia 2 isolates. The amino acid variations were $30-32 \%$ and $34-35 \%$ while the nucleotide differences were 15 - $16 \%$ and 18 - $19 \%$ for Asia 2 and Asia 1, respectively in comparison with the Onderstepoort strain in the signal peptide region. Both Asia 1 and Asia 2 isolates have common amino acids which differ from Ondestepoort. Moreover, each group has its specific amino acids. However, within the same group there is amino acid(s) characteristic to individual strain as in 007Lm ${ }^{116} \mathrm{Y} /{ }^{116} \mathrm{C}$ and inTh12 ${ }^{9} \mathrm{~T} /{ }^{9} \mathrm{~S}$ and ${ }^{26} \mathrm{R} /{ }^{26} \mathrm{~K}$ (Fig. 3).

\section{$F 2$ and $F I$ regions}

In the F2 region (aa136-224), amino acid differences were found as ${ }^{208} \mathrm{~N} /{ }^{208} \mathrm{~K}$ and ${ }^{216} \mathrm{~V} /{ }^{216} \mathrm{~L}$ in Asia 1 isolates, whereas ${ }^{186} \mathrm{D} /{ }^{186} \mathrm{G},{ }^{193} \mathrm{~S} /{ }^{193} \mathrm{~N},{ }^{195} \mathrm{~V} /{ }^{195} \mathrm{I}$ and ${ }^{216} \mathrm{~V} /{ }^{216} \mathrm{~L}$ in Asia 2 isolates but strains $50 \mathrm{Con}$ and $50 \mathrm{Cbl}$ have the same amino acid at positions 193 and 195 as Onderstepoort strain (Fig. 3).
The membrane anchored F1 subunit contains the fusion peptide (FP) domain (hydrophobic) at the N-terminus, trans-membrane (TM) domain (hydrophobic) and the cytoplasmic tail (CT) domain at the C-terminus. The fusion peptide domain was highly conserved among all CDV strains. On the other hand, amino acid changes were found in the TM domain as ${ }^{616} \mathrm{I} /{ }^{616} \mathrm{~S}$ in all Asia 1 isolates and ${ }^{627} \mathrm{C} /{ }^{627} \mathrm{Y}$ in all Asia 2 isolates. In the CT domain, six amino acid changes were observed within a span of 33 amino acid sequence. Common amino acid changes in all Asian isolates were found as ${ }^{640} \mathrm{~N} /{ }^{640} \mathrm{H}$ and ${ }^{646} \mathrm{~T} /{ }^{646} \mathrm{~A}$. Specific amino acid changes to all Asia 1 isolates were found as ${ }^{634} \mathrm{R} /{ }^{634} \mathrm{Q},{ }^{637} \mathrm{~F} /{ }^{637} \mathrm{~L}$ and ${ }^{639} \mathrm{H} /{ }^{639} \mathrm{Q}$ while those specific to Asia 2 isolates were found as ${ }^{637} \mathrm{H} /{ }^{637} \mathrm{~L}$ and ${ }^{656} \mathrm{R} /{ }^{656} \mathrm{~K}$. Strains 50Con and 50Cbl had the same amino acids at positions 637 and 656 as Onderstepoort strain.

Adjacent to these domains, heptad repeats were designated as HRA (aa 250-307), HB (aa 328-374) and HRB (aa 557-601), respectively [6,20,21] as shown in Fig. 3. Amino acid changes were found in $\mathrm{HB}$ domain as $366 \mathrm{~N} /$ ${ }^{366} \mathrm{G}$ in all Asian isolates and as ${ }^{600} \mathrm{~K} /{ }^{600} \mathrm{R}$ in HRB domain in Asia 1 isolates except for Yanaka strain while HRA domain was conserved

In other regions than the above described domains, common amino acid changes in all Asian isolates but different from Onderstepoort strain were found as ${ }^{317} \mathrm{~K} /{ }^{317} \mathrm{R},{ }^{431} \mathrm{~V} /$ ${ }^{431} \mathrm{I}$ and ${ }^{556} \mathrm{~S} /{ }^{556} \mathrm{G}$. Group specific change(s) was found as ${ }^{395} \mathrm{~V} / 395 \mathrm{I}$ in Asia 2 isolates while those were found as ${ }^{309} \mathrm{~L} /$ ${ }^{390} \mathrm{~F},{ }^{429} \mathrm{~K} /{ }^{429} \mathrm{R},{ }^{466} \mathrm{I} /{ }^{466} \mathrm{~L}$ and ${ }^{607} \mathrm{~S} /{ }^{607} \mathrm{G}$ in Asia 1 isolates, but strains Ac96I and Th12 have no amino acid difference at position 607 in compare to Onderstepoort strain. However, an unique amino acid to one or more strains in the same group was detected such as ${ }^{546} \mathrm{~S} /{ }^{546} \mathrm{G}$ for M25CR and $011 \mathrm{C},{ }^{478} \mathrm{G} /{ }^{478} \mathrm{C}$ for $81 \mathrm{ND}$ and ${ }^{482} \mathrm{~W} /{ }^{482} \mathrm{~L}$ for $50 \mathrm{Sc}$ strains as shown in Fig 3.

\section{$\mathbf{N}$-linked glycosylation sites and cysteine residues}

The F protein of Asian isolates had seven potential glycosylation sites (Fig. 3). Four of them were recognized at positions 141-143, 173-175, 179-181 in the $\mathrm{F} 2$ region and 517-519 in the F1 region as reported previously [16$18,21]$. Interestingly, the extra three potential glycosylation sites according to the consensus amino acid sequence for N-glycosylation site (N-X-S/T) were found in Asia 1 but not Asia 2 isolates, two at positions $62-64$ and 108110 in the signal peptide region were conserved in all Asia 1 strains while the site 605-607 in F1 region was found in some Asia 1 strains (50Sc, 81ND, 82Con and 83mLN). These seven glycosylation sites are shared by Taiwanese field isolates [22].

Cysteine amino acids are an important factor for the intra molecular disulfide bond and the steric structure of protein. As a result, a total 18 cysteine residues were detected 


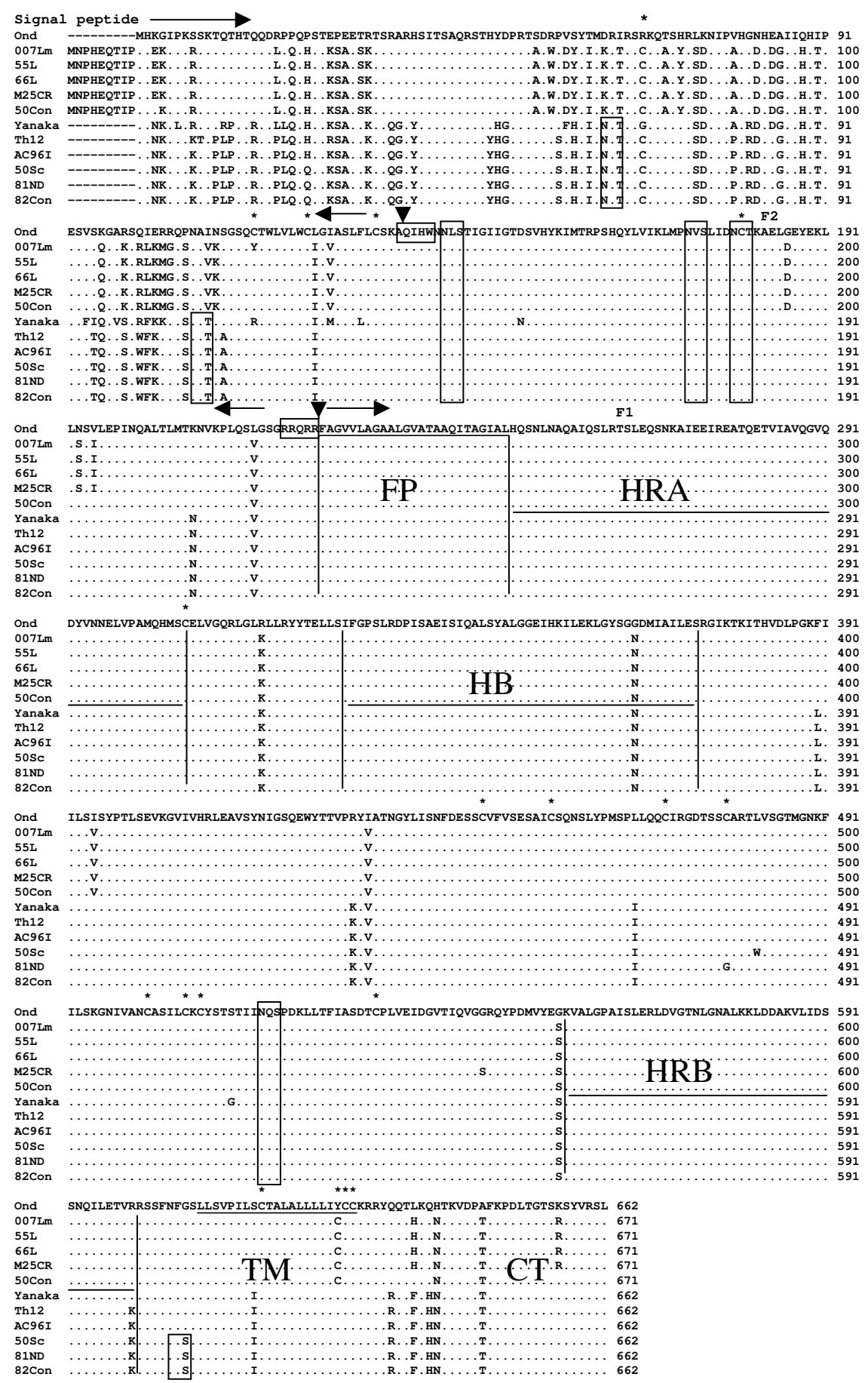

Figure 3

Alignment of deduced amino acid sequences of F genes of CDV strains. Only amino acids differ from the Onderstepoort sequence are shown. Potential $\mathrm{N}$-linked glycosylation sites $(\mathrm{N}-\mathrm{X}-\mathrm{S} / \mathrm{T})$ are boxed. Cysteine residues $(*)$, cleave sites $(\boldsymbol{\nabla})$, Hydrophobic regions are underlined. Domains in the F gene are Fusion peptide (FP), heptad repeats (HRA and HRB), helical bundles (HB), trans-membrane (TM), cytoplasmic tail (CT). Numbering starts at the first methionine residue of the Onderstepoort strain. The predicted amino acid sequences of the following pairs were identical; 66L/009L, M25CR/0 I I C, 50Con/50Cbl and $82 \mathrm{Con} / 83 \mathrm{mLN}$. 
in the F gene product; among them, fourteen residues were located at identical positions in all CDV strains (Fig. $3)$. Characteristic cysteine residues were located at positions $67,116,478$ and 627.

\section{Phylogenetic analysis of amino acids of $F$ genes}

The identities between the amino acid and nucleotide sequences of Asia 2 and these of Onderstepoort were $91 \%$ except for 50Con and 50Cbl (92\%), whereas identities between the amino acid and nucleotide sequences of Asia1 and Onderstepoort were $90 \%$ and $91 \%$, respectively as shown in Table 1 . Strains $66 \mathrm{~L}$ and $009 \mathrm{~L}, 011 \mathrm{C}$ and M25CR as well as strains $82 \mathrm{Con}$ and $83 \mathrm{mLN}$ showed $100 \%$ identities in both amino acid and nucleotide sequences. The similarity of strain Th12 was 99 and $98 \%$ to other Asia 1 strains in amino acids and nucleotides, respectively. While the similarity was 91 and $93 \%$ to all Asia 2 isolates in amino acids and nucleotide sequences except for strains 50Con and 50Cbl amino acid identity was $92 \%$ (Table 1 ).

The Phylogenetic analysis of $\mathrm{F}$ genes revealed that Asia 2 strains clustered into four clades; clade 50Con and $50 \mathrm{Cbl}$, clade $007 \mathrm{Lm}$, clade $011 \mathrm{C}$ and $\mathrm{M} 25 \mathrm{CR}$, clade $66 \mathrm{~L}, 55 \mathrm{~L}$ and 009L as shown in Fig. 4. On the other hand, Asia 1 isolates have five clades including clade Ac96I, clade Th12, clade $81 \mathrm{ND}$, clade $50 \mathrm{Sc}$, clade $82 \mathrm{Con}$ and $83 \mathrm{mLN}$. Interestingly, Asia 1 isolates were appeared to be closer to the European (5804) strain than American strains (A75/17, 98-2645, 00-2601, and 01-2689) when the phylogenetic relationship of F gene (Fig. 4) was compared with that of $\mathrm{H}$ gene (Fig. 1). In addition to this, the identical strains in $\mathrm{H}$ gene sequences such as $66 \mathrm{~L}, 009 \mathrm{~L}, \mathrm{M} 25 \mathrm{CR}, 011 \mathrm{C}$ and 007 Lm could be distinguished into three distant clades of Asia 2, and strains 82Con, 50Sc and 83meLN into two dis- tant clades of Asia 1 by $\mathrm{F}$ gene sequences analysis as shown in Fig. 4.

The phylogenetic relationship among various CDV strains based on the deduced amino acid sequences of the signal peptide region (Fig. 5) showed similar but not identical classification to that of F gene (Fig. 4).

\section{Discussion}

Although the presence of Asia 2 group of CDV was known previously by the sequencing and phylogenetic analysis of $\mathrm{H}$ gene [12], the characteristion of $\mathrm{F}$ gene or $\mathrm{F}$ protein of Asia 2 group had not been identified. In this study, the characteristic extra 27 nucleotides encoding extra 9 amino acids adding to the usual ORF of $F$ gene and the usual 662 amino acids of $F$ protein, respectively, were found for the first time in all Asia 2 isolates by sequencing analysis of $\mathrm{F}$ genes (Fig. 2 and 3). The extra 27 nucleotide sequences were identical and highly conserved among Asia 2 isolates. This fact indicates that Asia 2 isolates are easily distinguished from other CDV strains including Asia 1, American and European isolates, by this sequence.

The nucleotide change from ${ }^{4909} \mathrm{G}$ to ${ }^{4909} \mathrm{~T}$ led to the appearance of new initiation codon from position 4908 upstream of the usual F gene ORF (Fig. 2). Previous studies have suggested that translation of $\mathrm{F}$ protein starts at the first initiation codon, AUG1, or at the second codon, AUG61, that locates in the signal peptide region $[2,23]$. Adding to these in-frame AUGs, a new AUG appeared in Asia 2 isolates. Thus, producing an unusual long signal peptide, depending on the translation initiation codon used in the case of Asia 2 isolates.

The signal peptide region cleavage is necessary for the $\mathrm{F}$ gene activation and expression on the cell surface [2].

Table I: The identity of the deduced amino acid and nucleotide sequences of F genes of CDV Asian isolates.

\begin{tabular}{|c|c|c|c|c|c|c|c|c|c|c|c|}
\hline \multirow[t]{2}{*}{ Virus } & \multicolumn{11}{|c|}{$\%$ of identitya with: } \\
\hline & $007 \mathrm{Lm}$ & $55 \mathrm{~L}$ & $66 \mathrm{~L}^{\mathrm{b}}$ & $M 25 C R^{b}$ & 50 Con $^{\mathrm{b}}$ & Ac96I & ThI2 & $50 \mathrm{Sc}$ & 8 IND & 82 Con $^{b}$ & Ond \\
\hline 007Lm & & 99 & 99 & 99 & 99 & 92 & 91 & 91 & 91 & 91 & 91 \\
\hline $55 \mathrm{~L}$ & 99 & & 100 & 99 & 99 & 92 & 91 & 91 & 91 & 91 & 91 \\
\hline $66 \mathrm{Lb}^{\mathrm{b}}$ & 99 & 99 & & 99 & 99 & 92 & 91 & 91 & 91 & 91 & 91 \\
\hline$M 25 C R^{b}$ & 99 & 99 & 99 & & 99 & 92 & 91 & 91 & 91 & 91 & 91 \\
\hline 50 Con $^{b}$ & 99 & 99 & 99 & 99 & & 92 & 92 & 92 & 92 & 92 & 92 \\
\hline Ac961 & 92 & 92 & 92 & 92 & 93 & & 99 & 99 & 99 & 99 & 90 \\
\hline ThI2 & 93 & 93 & 93 & 93 & 93 & 98 & & 99 & 99 & 99 & 90 \\
\hline $50 \mathrm{Sc}$ & 92 & 92 & 92 & 92 & 93 & 99 & 98 & & 99 & 99 & 90 \\
\hline 8IND & 92 & 92 & 92 & 92 & 93 & 99 & 98 & 99 & & 99 & 90 \\
\hline 82 Con $^{b}$ & 92 & 92 & 92 & 92 & 93 & 99 & 98 & 99 & 99 & & 90 \\
\hline Ond & 91 & 91 & 91 & 91 & 92 & 91 & 91 & 91 & 91 & 91 & \\
\hline
\end{tabular}

a The identity of the deduced amino acid (upper half) and nucleotide (lower half) sequences of $F$ genes was found among CDV strains.

b Values shown are identical for cases $66 \mathrm{~L}$ and $009 \mathrm{~L}, \mathrm{M} 25 \mathrm{CR}$ and $01 \mathrm{IC}, 50 \mathrm{Con}$ and $50 \mathrm{Cb}$ and $82 \mathrm{Con}$ and $83 \mathrm{mLN}$. 


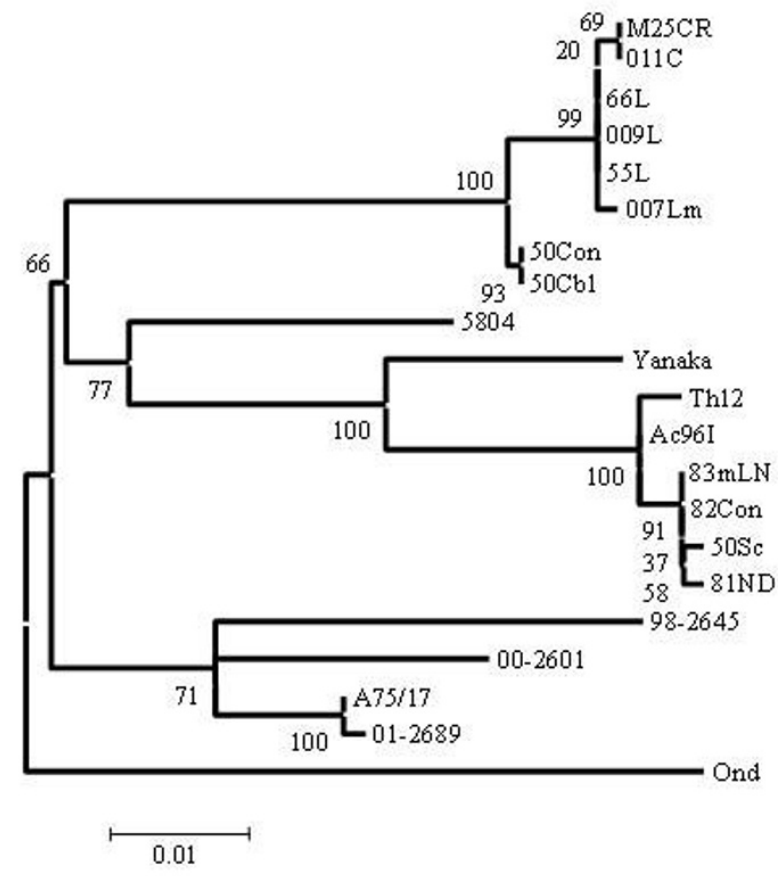

Figure 4

Phylogenetic analysis of deduced amino acid sequences of $F$ gene products of Asian isolates. Accession numbers of CDV strains are shown in the legend of Fig. I.

However, many reports have indicated that the potential function of this region is indirectly affecting the fusion activity of F protein and thus potentially contributing to neurovirulence, although this function was different for CDV strains $[2,6]$. So, the frequent variation observed in signal peptide region among Asian isolates may account for viral pathogenesis. In addition to the four conserved $\mathrm{N}$-linked glycosylation sites, three were found only in Asia 1 isolates. Previous studies suggested that N-linked glyco-

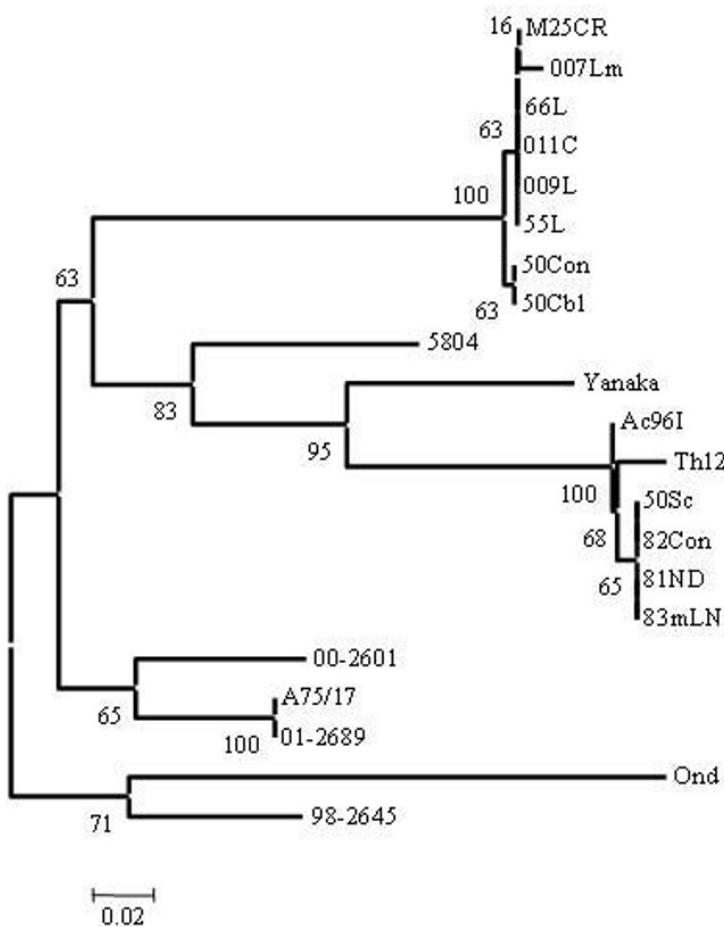

Figure 5

Phylogenetic analysis of deduced amino acid sequences of signal peptide region in the $F$ gene of Asian isolates of CDV. Accession numbers of canine distemper viruses are the same as shown in the legend of Fig. I.

sylation of viral envelope proteins ( $\mathrm{H}$ of measles virus, $\mathrm{F}$ of Newcastle disease virus, F of Nipah virus or prM of Japanese encephalitis virus) plays a number of critical roles in the virus life cycle and in virulence mechanisms such as binding to cell surface receptors and protecting against antibody neutralization [24-28], also the glycosylation might play an important role in the cleavage dependent

Table 2: Summarized data of CDV strains used in this study.

\begin{tabular}{|c|c|c|c|c|c|}
\hline Strain & Country & Organ & $\mathrm{H}$ accession number & F accession number & Reference \\
\hline 007Lm & Japan & Lymph node & $A B 212730$ & AB474397 & [3I] \\
\hline $55 \mathrm{~L}$ & Japan & Lung & AB295485 & AB475099 & Present study \\
\hline $66 \mathrm{~L}$ & Japan & Lung & $A B 295486$ & $A B 475100$ & Present study \\
\hline 009L & Japan & Lung & $A B 252718$ & AB475I0I & {$[3 I]$} \\
\hline M25CR & Japan & Cerebrum & AB475097 & AB475097 & Present study \\
\hline OIIC & Japan & Cerebellum & $A B 252717$ & AB47640I & {$[3 \mid]$} \\
\hline 50 Con & Japan & Conjunctiva & $A B 295483$ & AB476402 & Present study \\
\hline $50 \mathrm{Cbl}$ & Japan & Cerebellum & AB29548I & AB476403 & Present study \\
\hline Ac961 & Japan & Intestine & $A B 212963$ & $A B 512286$ & {$[10]$} \\
\hline Th 12 & Thailand & Brain & AB475098 & AB509344 & Present study \\
\hline $50 \mathrm{Sc}$ & Japan & Spinal Cord & AB295484 & AB509345 & Present study \\
\hline 8IND & Japan & Nasal discharge & AB295487 & AB50934I & Present study \\
\hline 82 Con & Japan & Conjunctiva & $A B 295488$ & AB509342 & Present study \\
\hline $83 \mathrm{mLN}$ & Japan & Mesenteric lymph node & AB295489 & $A B 509343$ & Present study \\
\hline
\end{tabular}


Table 3: Oligonucleotide primers used for RT-PCR amplification and nucleotide sequencing.

\begin{tabular}{|c|c|c|c|}
\hline Name & Sequence $\left(5^{\prime}-3^{\prime}\right)^{a}$ & Nucleotide position & Region \\
\hline $4754 \mathrm{~F}$ & ACTTGCCCGATCTCAAGCTA & $4754-4773$ & $M-F$ \\
\hline $5211 \mathrm{~F}$ & AGTGTCTCAAAAGGAGCGAG & $5211-5230$ & F gene \\
\hline $07-5379 F$ & GGACCGACAGTGTCCATTAT & $5380-5399$ & \\
\hline $5645 \mathrm{~F}$ & GGCTACAGCTGCACAAATCA & $5645-5664$ & \\
\hline $6210 \mathrm{~F}$ & ACTGTCCCGAGGTATGTTGC & $6210-6229$ & \\
\hline $675 \mathrm{IF}$ & TTGGCAGTCTCCTCAGTGTT & $6751-6770$ & \\
\hline CDV-HSI & AACTTAGGGCTCAGGTAGTCC & $7054-7074$ & $\mathrm{H}$ gene \\
\hline $766 \mathrm{IF}$ & GTAGGCAAAGTTTTCССССТ & $7661-7680$ & \\
\hline cdvhfl & TGTGTGTAGAAGAGAGCACTGT & $7962-7983$ & \\
\hline $8691 \mathrm{~F}$ & TTTATGACCCAATCCGGACG & $8691-8710$ & \\
\hline CDVHS2 & ATGCTGGAGATGGTTTAATTCAATCG & 8969-8994 & $\mathrm{H}-\mathrm{L}$ \\
\hline
\end{tabular}

a Forward and reverse primers in italic used for RT-PCR.

activation of the precursor F0 protein or in its transport to the sub-cellular region where the proteolytic cleavage occurs [29]. Our finding of different glycosylation sites of the $\mathrm{F}$ proteins suggested that these F proteins have different characters.

When compared to Asian isolates, European 5804 strain shared all $\mathrm{N}$-glycosaltion sites with Asia 1 except for that at position 605-607; in contrast American strains have the common four glycosylation sites as Asian isolates in addition to one site 108-110 shared by strains A75/17 and 012689.

Interestingly, strains Ac96I and Th12 have the same amino acids as Asia 2 at position ${ }^{23} \mathrm{H}$ and Th12 has unique amino acids at ${ }^{7} \mathrm{~K}$ and ${ }^{26} \mathrm{R}$. Also, Yanaka strain, Asia 1 isolate [9] has similar amino acids to Asia 2 isolates such as ${ }^{19} \mathrm{~L},{ }^{23} \mathrm{H},{ }^{84} \mathrm{D}$ and ${ }^{101} \mathrm{R}$ as well as unique amino acids at positions ${ }^{57} \mathrm{~F},{ }^{67} \mathrm{G},{ }^{4} \mathrm{~F},{ }^{95} \mathrm{I},{ }^{98} \mathrm{~V},{ }^{104} \mathrm{~K},{ }^{116} \mathrm{R},{ }^{126} \mathrm{M}$, ${ }^{130} \mathrm{~L},{ }^{151} \mathrm{~N}$ and ${ }^{513} \mathrm{G}$.

The genetic relationships shown in Fig 1 and 4 indicate that the field isolates form two separated lineages based on the deduced amino acids of F or H gene. Surprisingly, Asia 1 isolates appeared to be more closely related to European 5804 strain than to any other American strains by comparing the full $\mathrm{F}$ gene, while by $\mathrm{H}$ gene analysis, Asia 1 isolates were clearly distinguishable from European strain (Fig 1 and Fig. 4). Moreover, the phylogenetic analysis of the deduced amino acids of the signal peptide region of $\mathrm{F}$ genes is helpful for $\mathrm{CDV}$ classification giving a similar overview to that of the full $\mathrm{F}$ gene as shown in Fig 4 and 5.

\section{Conclusion}

The phylogenetic analysis of $\mathrm{F}$ gene gives clear picture for the $\mathrm{H}$ gene identical CDV strains and the signal peptide region gives a remarkable differentiation between Asia 1 and Asia 2 isolates.

\section{Materials and methods Cells and Viruses}

Vero.DogSLAMtag cells were established as described previously [30]. Cells were passaged and maintained in Dulbecco's modified Eagle's medium (D-MEM; autoclavable; Nissui Pharmaceutical Co. Ltd., Tokyo, Japan) supplemented with $10 \%$ fetal bovine serum in a $\mathrm{CO}_{2}$ incubator at $37^{\circ} \mathrm{C}$.

Fourteen CDV strains; 007Lm, 55L, 66L, 009L, M25CR, 011C, 50Con, 50Cbl, Ac96I, Th12, 50Sc, 81ND, 82Con and $83 \mathrm{mLN}$, were isolated and propagated, one or a few times, in Vero.dogSLAMtag cells and stored at $-80^{\circ} \mathrm{C}$ until use. Specimens were collected from diseased dogs as summarized in Table 2.

\section{Sequencing of $F$ and $H$ genes of $C D V$ and phylogenetic analysis}

Vero.DogSLAMtag cells were infected with virus suspensions at $\mathrm{MOI}=0.01$ and incubated for $18-24$ hours. When the CPE almost covered the cultures, total RNA was extracted using a MagExtractor ${ }^{\mathrm{TM}}$ RNA Extraction Kit (Toyobo Co., Ltd. Osaka, Japan) according to the manufacturer's instructions. Reverse transcription and PCR amplification (RT-PCR) were carried out using a ReverTraPlus- ${ }^{\mathrm{TM}}$-RT-PCR Kit (Toyobo Co., Ltd. Osaka, Japan). The primers used were as follows: 5'ACTTGCCCGATCTCAAGCTA $3^{\prime}$ and $5^{\prime}$ ATGCTGGAGATGGTTT AATTCAATCG 3'. The forward represents nucleotides 4754 4773 of the M-F region in the positive sense and the reverse represents nucleotides 8969 - 8994 of the H-L region in the negative sense. The amplified PCR products (4240 bp) were purified by using a Gene Clean II kit (Biogene, Inc., USA) after agarose gel (0.7\%) electrophoresis, and sequenced directly using a Big Dye ${ }^{\circledast}$ Terminator v.3.1 
cycle sequencing kit (Applied Biosystems, Inc., CA, USA), with appropriate primers designed according to an overlapping strategy Table 3 . The sequences were aligned by CLUSTAL W (1.83) Multiple Sequence Alignments (DDBJ) and phylogenetic analysis was carried out by the neighbor-joining method in Mega 3.1 program.

\section{Competing interests}

The authors declare that they have no competing interests.

\section{Authors' contributions}

SS conducted most of this work under supervision of KK and KM. NC participated in isolation of CDV strains and N-TL participated in isolation of CDV strains and determined the sequences of $\mathrm{H}$ and $\mathrm{F}$ genes of strains $007 \mathrm{Lm}$ and Ac96I under supervision of RY. All authors have read and approved the manuscript.

\section{Acknowledgements}

Serageldeen Sultan received financial support in the form of a $\mathrm{PhD}$ degree scholarship from the Egyptian government.

\section{References}

I. Lamb RA: Paramyxovirus Fusion: A hypothesis for changes. Virology 1993, 197: I-II.

2. Von Messling V, Cattaneo R: Amino-terminal precursor sequence modulates canine distemper virus fusion protein function. Journal of Virology 2002, 76:4172-4I80.

3. Scheid A, Choppin PW: Identification of biological activities of paramyxovirus glycoproteins. Activation of cell fusion, hemolysis, and infectivity of proteolytic cleavage of an inactive precursor protein of Sendai virus. Virology 1974, 57:475-490.

4. Asano K, Asano A: Why is a specific amino acid sequence of $\mathbf{F}$ glycoprotein required for the membrane fusion reaction between envelope of HVJ (Sendai virus) and target cell membranes? Biochemistry international 1985, 10:115-122.

5. Dutch RE, Jardetzky TS, Lamb RA: Virus membrane fusion proteins: biological machines that undergo a metamorphosis. Bioscience reports 2000, 20:597-6I2.

6. Plattet $P$, Cherpillod P, Wiener D, Zipperle L, Vandevelde M, Wittek $R$, Zurbriggen A: Signal peptide and helical bundle domains of virulent canine distemper virus fusion protein restrict fusogenicity. Journal of Virology 2007, 8 I: | | 4| 3- | | 425.

7. Bolt G, Jensen TD, Gottschalck E, Arctander P, Appel MJG, Buckland $\mathrm{R}$, Blixenkrone-Moller M: Genetic diversity of the attachment (H) protein gene of current field isolates of canine distemper virus. Journal of General Virology 1997, 78:367-372

8. Harder TC, Kenter M, Vos $H$, Siebelink K, Huisman W, van Amerongen G, Orvell C, Barrett T, Appel MJG, Osterhaus ADME: Canine distemper virus from diseased large felids: biological properties and phylogenetic relationships. Journal of General Virology 1996, 77:397-405.

9. Iwatsuki K, Miyashita N, Yoshida E, Gemma T, Shin Y, Mori T, Hirayama N, Kai C, Mikami T: Molecular and phylogenetic analyses of the haemagglutnin $(\mathrm{H})$ proteins of field isolates of canine distemper virus from naturally infected dogs. Journal of General Virology 1997, 78:373-380.

10. Lan NT, Yamaguchi R, Inomata A, Furuya Y, Uchida K, Sugano S, Tateyama S: Comparative analyses of canine distemper viral isolates from clinical cases of canine distemper in vaccinated dogs. Veterinary Microbiology 2006, I I 5:32-42.

1 I. Martella V, Cirone F, Elia G, Lorusso E, Decaro N, Campolo M, Desario C, Lucente MS, Bellacicco AL, Blixenkrone-Moller M, Carmichael LE, Buonavoglia C: Heterogeneity within the hemagglutinin genes of canine distemper virus (CDV) strains detected in Italy. Veterinary Microbiology 2006, I I 6:30 I-309.
12. Mochizuki M, Hashimoto M, Hagiwara S, Yoshida Y, Ishiguro S: Genotypes of canine distemper virus determined by analysis of the hemagglutinin genes of recent isolates from dogs in Japan. Journal of Clinical Microbiology 1999, 37:2936-2942.

13. Pardo IDR, Johnson GC, Kleiboeker SB: Phylogenetic characterization of canine distemper viruses detected in naturally infected dogs in North America. Journal of Clinical Microbiology 2005, 43:5009-5017.

14. Uema M, Ohashi K, Wakasa C, Kai C: Phylogenetic and restriction fragment length polymorphism analyses of hemagglutinin $(H)$ protein of canine distemper virus isolates from domestic dogs in Japan. Virus Research 2005, 109:59-63.

15. Ohashi K, Iwatsuki K, Nakamura K, Mikami T, Kai C: Molecular identification of a recent type of canine distemper virus in Japan by restriction fragment length polymorphism. The Journal of Veterinary Medical Science 1998, 60: 1209-1212.

16. Iwatsuki K, Miyashita N, Yoshida E, Shin YS, Ohashi K, Kai C, Mikami $\mathrm{T}$ : The nucleotide and predicted amino acid sequence of the fusion protein of recent isolates of canine distemper virus in Japan. The Journal of Veterinary Medical Science 1998, 60:38I-385.

17. Kövamees J, Blixenkrone-Möller M, Sharma B, Örvell C, Norrby E: The nucleotide sequence and deduced amino acid composition of the haemagglutinin and fusion proteins of the morbillivirus phocid distemper virus. Journal of General Virology I99I, 72:2959-2966.

18. Visser IKG, Heijiden RWJ van der, Bildt MWG van de, Kenter MJH, Örvell C, Osterhaus ADME: Fusion protein gene nucleotide sequence similarities, shared antigenic sites and phylogenetic analysis suggest that phocid distemper virus type 2 and canine distemper virus belong to the same virus entity. Journal of General Virology 1993, 74:1989-1994.

19. Plemper RK, Hammond AL, Cattaneo R: Measles virus envelope glycoproteins hetero-oligomerize in the endoplasmic reticulum. The Journal of Biological Chemistry 200 I, 276:44239-44246.

20. Baker KA, Dutch RE, Lamb RA: Structural basis for paramyxovirus-mediated membrane fusion. Molecular cell 1999, 3:309-319.

21. Barrett T, Clarke DK, Evans SA, Rima BK: The nucleotide sequence of the gene encoding the $F$ protein of canine distemper virus: a comparison of the deduced amino acid sequence with other paramyxoviruses. Virus Research 1987, 8:373-386.

22. Lee MS, Tsai KJ, Chen LH, Chen CY, Liu YP, Chang CC, Lee SH, Hsu $W L$ : The identification of frequent variations in the fusion protein of canine distemper virus. The Veterinary Journal 2008 in press. doi:10.1016/j.tvil.2008.10.001

23. Cherpillod P, Beck K, Zurbriggen A, Wittek R: Sequence analysis and expression of the attachment and fusion proteins of canine distemper virus wild-type strain A75/I7. Journal of Virology 1999, 73:2263-2269.

24. Aguilar HC, Matreyek KA, Filone CM, Hashimi ST, Levroney EL, Negrete OA, Bertolotti-Ciarlet A, Choi DY, McHardy I, Fulcher JA, Su SV, Wolf MC, Kohatsu L, Baum LG, Lee B: $\mathbf{N}$-glycans on Nipah virus fusion protein protect against neutralization but reduce membrane fusion and viral entry. Journal of Virology 2006, 80:4878-4889.

25. Kim JM, Yun SI, Song BH, Hahn YS, Lee CH, Oh HW, Lee YM: A single $\mathbf{N}$-linked glycosylation site in the Japanese encephalitis virus prM protein is critical for cell type-specific prM protein biogenesis, virus particle release, and pathogenicity in mice. Journal of Virology 2008, 82:7846-7862.

26. Moeller K, Duffy I, Duprex P, Rima B, Beschorner R, Fauser S, Meyermann R, Niewiesk S, ter Meulen V, Schneider-Schaulies J: Recombinant measles viruses expressing altered hemagglutinin $(H)$ genes: functional separation of mutations determining $\mathbf{H}$ antibody escape from neurovirulence. Jorunal of Virology 200I, 75:7612-7620.

27. Moeller-Ehrlich K, Ludlow M, Beschorner R, Meyermann R, Rima BK Duprex WP, Niewiesk S, Schneider-Schaulies J: Two functionally linked amino acids in the stem 2 region of measles virus haemagglutinin determine infectivity and virulence in the rodent central nervous system. Journal of General Virology 2007, 88:3112-3120.

28. Von Messling V, Cattaneo R: N-linked glycans with similar location in the fusion protein head modulate paramyxovirus fusion. Journal of Virology 2003, 77:10202-10212. 
29. Alkhatib G, Richardson C, Shen S-H: Intracellular processing, glycosylation, and cell-surface expression of the measles virus fusion protein (F) encoded by a recombinant adenovirus. Virology 1990, 175:262-270.

30. Seki F, Ono N, Yamaguchi R, Yanagi Y: Efficient isolation of wild strains of canine distemper virus in Vero cells expressing canine SLAM (CDI50) and their adaptability to marmoset B95a cells. Journal of Virology 2003, 77:9943-9950.

3I. Lan NT, Yamaguchi R, Uchida K, Sugano S, Tateyama S: Growth profiles of recent canine distemper isolates on Vero cells expressing canine signaling lymphocyte activation molecule (SLAM). Journal of Comparative Pathology 2005, 133:77-8I.

Publish with Bio Med Central and every scientist can read your work free of charge

"BioMed Central will be the most significant development for disseminating the results of biomedical research in our lifetime. "

Sir Paul Nurse, Cancer Research UK

Your research papers will be:

- available free of charge to the entire biomedical community

- peer reviewed and published immediately upon acceptance

- cited in PubMed and archived on PubMed Central

- yours - you keep the copyright

Submit your manuscript here:

http://www.biomedcentral.com/info/publishing_adv.asp 